\title{
Indonesian Composer's Piano Work in the Piano Education Curriculum
}

\author{
Hendrik Leonard Simanjuntak ${ }^{1}$, Lono Lastoro Simatupang ${ }^{1, ~ *, ~ V i k t o r ~ G a n a p ~}{ }^{2}$ \\ ${ }^{1}$ Performing Arts and Fine Arts Studies, Graduate School of Gadjah Mada University, Yogyakarta, Indonesia \\ ${ }^{2}$ Faculty of Performing Arts, Yogyakarta Indonesian Institute of the Arts, Yogyakarta, Indonesia
}

Email address:

hendrik.1.s@mail.ugm.ac.id (H. L. Simanjuntak), lono_simatupang@yahoo.com (L. L. Simatupang), victor.ganap@yahoo.com (V. Ganap)

${ }^{*}$ Corresponding author

\section{To cite this article:}

Hendrik Leonard Simanjuntak, Lono Lastoro Simatupang, Viktor Ganap. Indonesian Composer's Piano Work in the Piano Education Curriculum. International Journal of Education, Culture and Society. Vol. 6, No. 3, 2021, pp. 85-91. doi: 10.11648/j.ijecs.20210603.13

Received: May 22, 2021; Accepted: June 7, 2021; Published: June 15, 2021

\begin{abstract}
Indonesia is an archipelago that stretches from Sabang to Merauke and has various traditions, cultures, religions and arts. Diversity is a source of inspiration for Indonesian piano composers in creating piano works that have an Indonesian identity. Amir Pasaribu became the first composer to use Indonesian musical idioms in piano composition and was followed and continued by Mochtar Embut. Trisutji Kamal, Jaya Suprana, and Ananda Sukarlan began to expand the use of musical materials from various regional music in Indonesia. The various compositions they have compiled have also inspired pianists by making their works as a repertoire of choice during performances or recitals, both nationally and internationaly. The Indonesians recognized their work and made it a way of supporting the expansion of the piano curriculum system. Formal and non-formal institutions have begun to use Indonesian piano work as learning material in music education. The HKBP Nommensen University Music Arts Study Program revised their curriculum and then included new courses, namely; Piano Wajib (Compulsory Piano) courses for two semesters. This subject specifically studies and trains various piano works of Indonesian composers. Several other institutions, such as; Sekolah Musik Yayasan Pendidikan Indonesia (The Indonesian Education Foundation's Music School), Jaya Suprana School of Performing Arts, Institut Seni Indonesia Yogyakarta (Yogyakarta Indonesian Institute of the Arts), Life On Piano Music Center also uses the piano works of Indonesian composers as a repertoire of music learning options. However, the authors see that until now there has been no adequate source, both writings, research, and seminars that discuss Indonesian piano works in depth. For example the topic of how their works are put in the trajectory of piano history? How do Indonesian composers' piano works position in the curriculum? This study provides discourse on Indonesian piano work as a grade-based educational curriculum. This curriculum can be implemented by the Indonesian education authorities for adjustment or revision of their curriculum.
\end{abstract}

Keywords: Curriculum, Composer, Piano, Indonesia

\section{Introduction}

Indonesian music or also understood as Indonesian classical music is an effort made by Indonesian composers to compose musical works as a way of caring for and maintaining musical and cultural diversity in the archipelago. The richness of the diversity of this nation's musical material is a gift and also a great potential that must be exploited and developed to build an identity for Indonesian classical music, both nationally and internationally.

The works of Indonesian composers have used by some music education schools. Through field observations, the author found several formal and non-formal institutions use Indonesian composers' piano works in learning piano music, such as: Life on Piano Music Center. This institution uses piano works composed by Levi Gunardi. Many of his works were collected in his book album, Imaginary Word, which is specially designed as a repertoire for children's concerts. Gunardi said that the works compiled in Imaginary Word are an attempt to introduce them to various song characters and diverse imaginations. Children learn a variety of different piano techniques with each piece. To support a fun learning process for children, the composer combined songs with 
interesting illustrations. Hopefully, this collection of songs can help the development of Indonesian classical music [1].

Jaya Suprana School and Performing Arts uses Indonesian composers' piano work in piano lessons, but still has an alternative choice of repertoire for recitals and concerts. According to Iqbal as Head of the Music Division, "the curriculum used is still adopting the western music curriculum, however, there is an open space to study piano works of Indonesian composers for recitals and performances" [2]. The works performed by students, teachers, and other pianists were the composition of the piano Jaya Suprana, such as Tembang Alit, Fragmen [3], Dedemit [4], Rhapsodia Lir-Ilir [5], a collection of works by Untuk Ayla [6], Uro-Uro [7], and Fantasia Arum Dalu [8].

The Music Arts Study Program at HKBP Nommensen University has used Indonesian composer piano work as learning material in the Compulsory Piano Course since 1996. According to Ance Panggabean, "As a student of the 1992/1993 class at the Faculty of Arts, HKBP Nommensen University, I did not have the chance to get the Compulsory Piano Course. We are still using the 1987 piano curriculum compiled by Rhoderick J. McNeill, Edward C. Van Ness, and team. The Compulsory Piano course, which specifically studied the piano works of Indonesian composers, was included in the 1996 curriculum revision when Ben M. Pasaribu headed the Faculty of Arts" [9].

On the one hand, the efforts by the Music Arts Study Program of HKBP Nommensen University should be appreciated as a part of nationalism and appreciation for Indonesian composers. But on the other hand, no steps have been taken to compile an Indonesian piano curriculum that can be a reference for students even though it has been going on for decades. So it is not surprising if in its implementation problems arise due to the absence of a guide that can be understood by lecturers and students. Kamaluddin Sigalingging states that, "the use of Indonesian composers' piano works in the Faculty of Arts curriculum from one side should be appreciated, but on the other hand, the implementation is a bit confusing because students with major piano interests also take compulsory piano courses. In terms of difficulty level, these students are relatively much able to learn Indonesian piano work when compared to students majoring in guitar, vocals, violin, flute, saxophone, etc" [10].

This statement cannot be separated from the initial condition when the course was started. Access to search for piano works at that time was still difficult because the composers had not published them in books. The piano works of Mochtar Embut and Amir Pasaribu such as Impressi Langar, Variasi Sriwijaya, Indhiyang, Kuda Lumping, Kamadjaja, Suita Kaliurang, etc. are still in handwritten form. This limited access reduces the space for students to choose work according to their ability level. Around 2000, Trisutji Kamal, Jaya Suprana, and Ananda Sukarlan began documenting their works in books.

The purpose of this study is to discuss the use of Indonesian composers' piano works in the music education curriculum in formal and non-formal institutions. This discourse cannot be separated from various field facts found by the author. For example, the use of works as learning materials in formal and non-formal institutions; Indonesian piano compositions are the preferred repertoire for pianists in various musical performances and recitals; and Indonesian piano compositions have become the object of research.

Some of the questions that serve as guidelines in this research are;

1) What is the concept of compositional work offered by Indonesian composers in their works?

2) What is the current piano education system in Indonesia?

3) How is the design of the piano education curriculum in Indonesia which is discussed based on grade?

\section{Performance of Indonesian Composers' Piano Works}

The piano works of Indonesian composers have become a repertoire for recitals and concerts for pianists. Some of them are as follows; Edith Widayani performed Ananda Sukarlan's Rapsodia Nusantara No 8 and Rapsodia Nusantara No 10 at the Doctor of Musical Arts recital program at Hatch Recital Hall, Eastman School of Music - Rochester, New York; Natalia González Figueroa performing Rapsodia Nusantara No 11 by Ananda Sukarlan in Buenos Aires, Argentina (this work is specifically dedicated to the composer Natalia González Figueroa); Natassja Debra performing Tembang Alit and Fragmen by Jaya Suprana at the graduation recital of the Applied Music Program-Mohawk College, Canada; Muhammad Iqbal Siddiq presented Fragments of Jaya Suprana's work at the recital program at Jaya Suprana School of Performing Arts; Phil Jinxie and Nizieta Fatimah Azzahra performing Levi Gunardi's Little Gamelan at the Life On Piano Music Center; Mahening Citra Vidya performed Trisutji Kamal's Tari Pohon dan Daun yang Berguguran at the Indonesian Student Association program, Indonesia 2018 at Cultuur TU Delft, The Netherlands; Martin Kesuma presents Kamadjaja for the educational program at the University of Texas; and Teodore Minaroy performed Amir Pasaribu's Indyhiang at the Puspawarna Indonesiaku Concert at the Makara Art Center Auditorium.

Through this musical performance, pianists have directly participated in introducing the musical richness of the archipelago to the community. Indonesian piano works, which are arranged based on the idiom of Indonesian music and folk songs, have become a new medium for the public to access and learn various musical treasures through the piano instrument. Ananda Sukarlan said, "I think that the elements of Indonesian music can be raised in different media while still paying attention to aspects of melody, rhythm and technique. Every composition that I compile sometimes uses or combines several musical elements from several regions depending on the situation in which the work is played" [11]. 
This perspective can be understood as a space for creativity for Indonesian composers to work. The use of archipelago musical elements can reduce Indonesian composers from the limitations of 'standard' composing a work with the concept of western classical tradition. The expansion of creative composition schemes is a necessity for Indonesian composers in elaborating and discovering novelty ideas and ideas in composition.

\section{Composition Concept}

Indonesian composers who have worked with a grammatical approach to combining Indonesian and Western music since Ki Hajar Dewantara, Ismail Marzuki, Cornel Simanjuntak, Amir Pasaribu, Mochtar Embut, Trisutji Kamal, Jaya Suprana, and Ananda Sukarlan. Dewantara states that music must be able to express the innermost soul of man. The freedom of performers in their performances can give them a deeper ability to express Indonesian work [12]. Raden states that Ismail Marzuki Cornel Simanjuntak was a composer who composed many songs for the struggle for Indonesian independence. The works that are composed still adhere to the norms of lyric and melodic composition [13].

Amir Pasaribu was the first composer to compose piano pieces in Indonesia and was followed by Mochtar Embut. Their works tend to be inspired by Javanese and Balinese musical idoms which we can find in their works such as; Variasi Sriwijaya, Indyhiang, Tjapung Ketjimpung di Tjikapundung, dan Sibongkok dengan Sulingnya by Amir Pasaribu; and Kamadjaja and Suita Kaliurang by Mochtar Embut. However, in the next generation, Trisutji Kamal, Jaya Suprana, and Ananda Sukarlan began to expand the use of musical materials in the composition of works.

Trisutji Kamal began to expand the concept of composition by utilizing various musical materials derived from various Indonesian musical idioms which were not only focused on Javanese and Balinese gamelan music. Composers also expanded the use of musical materials derived from folk songs found in various parts of Indonesia. Trisutji Kamal began to use chromatic scales as the basis for building the Sundanese Seascapes composition, which consists of seven works, such as; Nuansa Selat Sunda, Misteri Pulau Sanghyang, Pasang Surut, Cumbuan Bulan dan Laut, Gitaya Samudra, Senja Di Pantai Ayer, dan Angin Barat [14]. The chromatic composition of the Sundanese Seascapes is a sign that the composer wants to break away from the tonal music hierarchy as in his previous works (Rambadia, Tokecang, Tudung Saji, Madegdeg, Anju Ahu, Jali-Jali, Bungong Jeumpa and Kicir-Kicir.) Referring to Burnett and Nitzberg states, using of chromatic is basically to increase tension and it's the composer to determine the tonality chosen. Therefore, the composer must carefully choose chromatic tones, either as decoration in a melody or motif, or as a chord structure [15].

Jaya Suprana has his own opinion regarding work-making activities by saying "when composing a work, I did not think about music theory, but just trying to express the contents of my conscience deep down, so I cannot explain why my work is more homophonic than polyphonic" [16]. Through analytical activities, we found that Jaya Suprana paid serious attention to the balance of the composition structure. Composers enjoy the vigilance of lyrical melodies making homophonic accompaniment the best choice.

Ananda Sukarlan is a prolific Indonesian piano composer who continues to compose new works until now. The concept of Ananda Sukarlan's composition is similar to that of Trisutji Kamal, using of various Indonesian musical idioms and Indonesian folk songs as a source of inspiration for composing works. However, Ananda Sukarlan gave a different way by presenting various musical materials sourced from regions outside Indonesia which can be found in Alicia's Piano Book I-VI. We can find piano works with virtuoso technique in Rapsodia Nusantara No. 1-34 based on the idiom of Indonesian music and folk songs. For example, Rapsodia Nusantara No. 1 was prepared using a multi-scale approach such as; whole note scale (bar 1-40; major / minor scale (bar 16-21); Phrygian mode (bar 68-76); Kicir-Kicir and Jali-Jali melodic fragmentation in various levels (bar 12-21; 88- 94; and 105-111). Rapsodia Nusantara became Ananda Sukarlan's master work, and these works became the repertoire of piano concerts and recitals.

\section{Indonesian Piano Education System}

Basically, the Indonesian piano music curriculum still uses or adopts the concept of the Western piano music curriculum, but over time there has been a relaxation of the piano curriculum which is marked by the inclusion of Indonesian composers' piano works into learning material. However, the existence of Indonesian composers' piano works as learning material has not been thoroughly applied in formal and non-formal education. This is due to different perspectives and absence of literature [17].

On the one hand, formal and non-formal education places Indonesian composers' piano works as a hidden curriculum that synergizes with the official curriculum. For example, Indonesian composers' piano works were studied as necessities for piano concerts, or recitals. But on the other hand, formal and non-formal education places the works of Indonesian composers' piano as the main learning material. This means that these works become an integral part of the official educational curriculum. The Music Education Foundation School of Music under the leadership of Iravati M. Sudiarso requires every student to learn piano works by Indonesian composers. Arabesk and Berceuse II work as mandatory repertoire for levels IV and IV. This can be seen in Trisutji Kamal's book Komposisi untuk Piano Tunggal, published in 1983 [18].

The HKBP Nommensen University Music Arts Study Program has determined that all students in the third and fourth semesters take Compulsory Piano I and II courses. Compulsory Piano I and II course materials specifically study the works of Indonesian composers' pianos. One of the figures behind the discourse on learning Indonesian piano works in 
the course is Ben M. Pasaribu, who thought that students needed to be equipped with knowledge of the character and composition style of Indonesian composers' works.

The concept of the piano music curriculum is generally derived in a piano learning system known as grade. The learning material in each grade is designed according to clear stages. This means that students who complete the grade if they have completed all the learning material properly according to the guidelines. Based on an analysis of the three piano curriculum of the Associated Board of the Royal School of Music [19], London College of Music [20], and Trinity College London [21], we found that there are at least four sections that must be mastered by students in order to complete one particular grade, such as; repertoire (pieces), scales, sight-reading, and aural. The loose part of the four sections is the repertoire. Institutions have the discretion to select piano pieces according to grade and other three-part adjustments.

The four parts in piano learning as mentioned above are actually in accordance with the discourse of Labuta and Smith which states that the curriculum is a skill; as knowledge; and as a learning method. The ability to play and display piano works well according to grade is the final part of the learning process which can also be interpreted as skills that students have. The repertoire is generally organized into three categories which are an exploration of various musical traditions and styles, dating from the Renaissance period to the present [22]. ABRSM provides guidance in terms of arranging repertoires based on three categories, namely; (1) piano works that are composed with a faster tempo and require technical dexterity; (2) works that are more lyrical (full of feeling) and emphasize expressive play; and (3) piano works that reflect a variety of musical traditions, styles and characters. Aural test is a part for students that aims to develop their knowledge not only in terms of practice, but a more through understanding. Aural test as a part for students to be able to understand how music works by listening; understand dynamics and play according to the tempo, rhythm, beat; able to identify pitch (interval); remembering a musical part or structure; and the ability to identify errors or differences when a piece is played twice differently in a particular section. Scale is a method designed to build strong technical skills of students by playing scales and arpeggios. The benefit of this method is to control finger movement, hand position, coordination, and smoothness of the fingers on piano keys. This method also helps students to develop knowledge on basic tones and intervals; mastering scales and related patterns; and tone controls. Mastery of a good scale can lead to self-confidence and comfort when learning new works and during performances, both solo and ensemble. Sight-reading is a method used to help students develop their ability to identify common tones and rhythm patterns in scores. This method also encourages students to learn new works more quickly, easily, and helps compose works.

The author has more than a decade of experience and is directly involved in implementing the piano curriculum in several informal educational institutions, such as; Medan
Musik, Purwacaraka Music Studio and Yamaha Music Studio. Over time, the authors began to realize that there were fundamental problems in the Indonesian piano curriculum that had been going on so far related to ambiguity in cultural understanding. Our position as teachers or instructors is of course in charge of running the existing curriculum, and sometimes we don't realize that the curriculum material being taught fully contains works that come from outside our own culture.

Although currently it is possible for us to access a lot of information about western culture by surfing the internet, but in terms of musical identity and our understanding of these cultures is limited because we are not really involved and interact directly in their culture. For example, a piano teacher who teaches the song London Bridge is Falling Down to children aged 4-5 years must have difficulty in explaining and relating this song to the condition or situation of the bridge in question; describes the activities that take place around the bridge; and describes possible historical aspects it may have.

Therefore, the final steps taken by the teachers usually focus on teaching how to play the melody and accompaniment according to the notes written on the score. Piano learning as described above is not only found in students aged 4-5 years, but also experienced by other learners at various levels. This situation has been going on for a long time and it takes efforts that must be made by the competent authorities and also other stakeholders to rethink the existence of a piano curriculum that is accommodating to its own culture.

The thoughts of Jorgensen about the design of the music curriculum can be used as an entry point for us to see the existence of the piano curriculum. The curriculum should not be understood as a "static system" or an "immutable standard"; but we should understand it as a "dynamic system" or "can be changed" as needed [23]. Therefore, we are discussing the need to accommodate the works of Indonesian composers in the piano education curriculum in Indonesia. This discourse is not aimed at eliminating or negating the importance of the piano curriculum that has been going on in Indonesia, but on the contrary, to complement and enrich the existing curriculum. Students get space and the opportunity to learn piano works which are arranged based on Indonesian idioms and regional music. The presence of Indonesian music elements contained in piano works helps pianists or students interpret the works. In addition, Indonesian piano works are also pieces to build the identity of Indonesian pianists when performing overseas.

Edith Widayani said as a pianist, "I and other Indonesian pianists are always looking for and then playing new pieces in addition to the existing piano repertoire. We as pianists also seek identity. When I hold performances abroad, I see how enthusiastic the audience responds to Rapsodia Nusantara's work. I enjoy playing works that show our own identity at concerts, and through these works I also offer something 'new' to outsiders" [24]. The presence of Indonesian piano works has an important contribution not only for Indonesian pianists, but also enriches their knowledge in the field of musical composition. The new 
characters offered by Indonesian composers also broaden our perceptions of scale, rhythm and timbre.

The piano works by Indonesian composers can be graded according to the general piano grade. This really needs to be done with the aim that Indonesian piano works can be considered and then accommodated to become an integral part of the Indonesian piano education system. Based on the research data that has been collected, we see that further analysis is needed in order to place Indonesian piano pieces in what grade. The grading of Indonesian piano pieces is based on the considerations made by ABRSM, LCM, and Trinity in determining the grade.

\section{Composition Piano Work Grades}

We designed and placed piano pieces composed by Amir Pasaribu, Mochtar Embut, Trisutji Kamal, Jaya Suprana and Ananda Sukarlan in a grade system based on considerations in grading as already explained. The following table is arranged from first grade to advance grade, and the works shown below are part of the curriculum we have compiled. The complete design of this Indonesian composition piano curriculum can be seen in the author's dissertation, Indonesian Composers Piano Composition: Indonesian Identity Study.

The first grade is structured by considering the use of arpeggios and tonality of works arranged in $\mathrm{C}$ major, $\mathrm{G}$, major, $\mathrm{F}$ major, $\mathrm{D}$ major, $\mathrm{A}$ minor, and $\mathrm{D}$ minor scales. Melodies and harmonies are arranged in small intervals not exceeding two octaves.

Table 1. Indonesian Piano Composition First Grade.

\begin{tabular}{llll}
\hline Work & Mov & Key & Composer \\
\hline Slow Waltz & 1 & $\mathrm{a}$ & Ananda Sukarlan \\
Advance I & 1 & $\mathrm{~F}$ & \\
Advance II & 1 & $\mathrm{C}$ & \\
Black and White & 1 & $\mathrm{C}$ & Trisutji Kamal \\
Hymne & 1 & $\mathrm{~g}$ & \\
Panembrama & 1 & $\mathrm{C}$ & \\
Preludio & 1 & $\mathrm{c}$ & \\
\hline
\end{tabular}

The works composed for the second grade were expanded, both in terms of scales (A major, E mayor, and E minor) and melodic arrangement. Various works in the A major scale can be seen in table 2, such as; An Alien's Waltz, Hand in Hand by Ananda Sukarlan, and Alun-Alun by Trisutji Kamal.

Table 2. Indonesian Piano Composition Second Grade.

\begin{tabular}{llll}
\hline Work & Mov & Key & Composer \\
\hline A Haunted Old Church & 1 & $\mathrm{C}$ & Ananda Sukarlan \\
Rag & 1 & $\mathrm{~F}$ & \\
An Alien's Waltz & 1 & $\mathrm{~A}$ & \\
Hand in Hand & 1 & $\mathrm{~A}$ & \\
Alun-alun & 1 & $\mathrm{~A}$ & Trisutji Kamal \\
Ammae Ciang & 1 & $\mathrm{C}$ & \\
Kupu Kuning & 1 & $\mathrm{G}$ & \\
Ampar-ampar Pisang & 1 & $\mathrm{~F}$ & \\
Lagu Manju & 1 & $\mathrm{a}$ & \\
\hline
\end{tabular}

The third grade is expanded using the scale of $\mathrm{Bb}$ major, $\mathrm{Eb}$ major, $\mathrm{G}$ minor, $\mathrm{C}$ minor. The arrangement of the melody and arpegio in two octaves is a realm of possibility. Pinang Muda by Trisutji Kamal is composed based on a regional song from East Sumatra and uses the key of $\mathrm{Bb}$ major. This work is characterized by interval 11 and syncopation.

Table 3. Indonesian Piano Composition Third Grade.

\begin{tabular}{llll}
\hline Work & Mov & Key & Composer \\
\hline In Javanese Village & 1 & $\mathrm{D}$ & Ananda Sukarlan \\
Midsummer's Daydream & 1 & $\mathrm{~A}$ & \\
Under the Blur Autum Sky & 1 & $\mathrm{a}$ & \\
Dangdut & 1 & $\mathrm{~d}$ & \\
Bungong Jeumpa & 1 & $\mathrm{a}$ & Trisutji Kamal \\
Pinang Muda & 1 & $\mathrm{Bb}$ & \\
O Ina ni Keke & 1 & $\mathrm{C}$ & \\
Saule & 1 & $\mathrm{D}$ & \\
Ting Dodaij & 1 & $\mathrm{D}$ & \\
Pantun Jenaka & 1 & $\mathrm{~F}$ & \\
\hline
\end{tabular}

Several works were compiled for grade 4 using the tonality changes seen in Rambadia in the chord of $G$ major and modulation in $\mathrm{G}$ minor; Tarian Fantasi are arranged in tonality $\mathrm{G}$ major and modulation in E major; Kepergian are composed of tonality $\mathrm{C}$ major and modulated Lydian $\mathrm{C}$ with alterations to the notes $\mathrm{Bb}$ and $\mathrm{Ab}$.

Table 4. Indonesian Piano Composition Fourth Grade.

\begin{tabular}{llll}
\hline Work & Mov & Key & Composer \\
\hline Untuk Ayla 1 & 1 & $\mathrm{~A}$ & Jaya Suprana \\
Untuk Ayla 2 & 1 & $\mathrm{e}$ & \\
Untuk Ayla 3 & 1 & $\mathrm{C}$ & \\
Untuk Ayla 4 & 1 & $\mathrm{e}$ & \\
Quasi Tokecang & 1 & $\mathrm{C}$ & Ananda Sukarlan \\
A Prosthetic Leg's Waltz & 1 & $\mathrm{C}$ & \\
Woo the Boogie & 1 & $\mathrm{C}$ & \\
Kepergian & 1 & $\mathrm{C}$ & Trisutji Kamal \\
Rambadia & 1 & $\mathrm{G}$ & \\
Tarian Fantasi & 1 & $\mathrm{G}$ & \\
Tiupan Angin Malam & 1 & $\mathrm{~Eb}$ & \\
Mengayun-Ayun & 1 & $\mathrm{E}$ & \\
\hline
\end{tabular}

The use of arpeggios and extended melodic arrangement causes tonality to occur in various chords. Impresi Langgar is arranged in $\mathrm{E}$ minor and modulation on the key of $\mathrm{E}$ major which is found in bar 51. The Juggler's Meeting also experienced the same thing, the work is arranged in the key of $\mathrm{F}$ minor and modulation to $\mathrm{Db}$ major on bar 38. The use of fifth interval on the melody is Amir's style Pasaribu on his works.

Table 5. Indonesian Piano Composition Fifth Grade.

\begin{tabular}{llll}
\hline Work & Mov & Key & Composer \\
\hline Impressi Langgar & 1 & $\mathrm{G}$ & Amir Pasaribu \\
The Juggler's Meeting & 1 & $\mathrm{f}$ & \\
Si Bongkok dengan Sulinganya & 1 & $\mathrm{Bb}$ & \\
Kuda Lumping & 1 & $\mathrm{D}$ & Mochtar Embut \\
Anak Perahu & 1 & $\mathrm{E}$ & \\
Valse & 1 & $\mathrm{f} \#$ & \\
Intermezzo & 1 & $\mathrm{G}$ & Trisutji Kamal \\
Serenade Seorang Pengemis & 1 & $\mathrm{G}$ & \\
Tafakur Tombo Ati & 1 & $\mathrm{G}$ & Jaya Suprana \\
Happy Days & 1 & $\mathrm{~F}$ & Ananda Sukarlan \\
Funky Fanfare & 1 & $\mathrm{Ab}$ & \\
Scherzando & 1 & $\mathrm{C}$ & \\
\hline
\end{tabular}


Works arranged in the sixth grade are based on all major / minor scales and pentatonic scales. In addition, the expansion of the composition concept occurred with the use of bi-tonality in Jaya Suprana's Dolanan. Mochtar Embut's Suita Kaliurang does not take the standard pattern of Bach's suite, both in terms of key and dance. The composer chose to use the Indonesian musical idiom as a material for composing dance titles and works with a place or person associated with Indonesia (Getuk Lindri, Rumah Gadang, Merapi, and Keluarga Pak Pawira.) Tembang Alit, and Fragmen are compositions based on Javanese and Bali musical idioms. Ananda Sukarlan expanded the concept of Passacaglia composition by using 4/4 meter, themes arranged along 4 bars, melody and harmony organization based on pentatonic slendro.

Works that are placed in the seventh grade are arranged according to all major / minor scales and pentatonic scales. Amir Pasaribu's Mazurka has a similarity with Chopin's mazurka concept, in the use of 3/4 rhythms, decorative tones, and the use of the Lydian mode. Amir Pasaribu made an expansion in terms of the structure of the mazurka, arranging this work in two movements. Suita Marzukiana by Jaya Suprana also does not take the Bach suite concept either in terms of tonality and dance patterns. The composer organized this work into seven parts; Fajar Harapan (C major) - Payung Fantasi (G major) - Lambaian Bunga (D major) - Rindu (C major) - Wanita (C major) - Sabda Alam (C major) - Bung Dimana (C major).

Table 6. Indonesian Piano Composition Sixth Grade.

\begin{tabular}{llll}
\hline Work & Mov & Key & Composer \\
\hline Puisi Bogor & 1 & F & Amir Pasaribu \\
Suita Kaliurang & 4 & e & Mochtar Embut \\
Sonatine in A & 3 & A & \\
Yang Kembali Besemi & 1 & G & Trisutji Kamal \\
Tari Pohon & 1 & a & \\
Berceuse II & 1 & d & \\
Tembang Alit & 1 & F & Jaya Suprana \\
Epitaph 1 & 1 & G & \\
Fragmen & 1 & e & \\
Dolanan & 1 & Bi-tonality & \\
Alicia's First Variations & 1 & C & Ananda Sukarlan \\
Passacaglia & 1 & Phrygian C & \\
\hline
\end{tabular}

Table 7. Indonesian Piano Composition Seventh Grade.

\begin{tabular}{llll}
\hline Work & Mov & Key & Composer \\
\hline Mazurka & 1 & C Aeolian & Amir Pasaribu \\
Suita Senda Tjendikias & 4 & $\mathrm{e}$ & \\
Arabesk & 3 & $\mathrm{a}$ & Trisutji Kamal \\
Sungai & 1 & $\mathrm{~Eb}$ & \\
Suita Marzukiana & 7 & $\mathrm{C}$ & Jaya Suprana \\
Tri Reminiskensa & 3 & Eb & \\
12 Haiku & 1 & Chromatic & Ananda Sukarlan \\
Furiously Funky & 1 & Chromatic & \\
\hline
\end{tabular}

The works that are placed in the 8th grade are arranged according to all major / minor scales, modes, chromatic, pentatonic, and intervalic scales. Variasi Sriwijaya are inspired by Gending Sriwijaya from South Sumatra, and a unique arrangement occurs in Variasi V and VI with the presence of keroncong music material. Tjapung Ketjimpung di Tjikapundung is composed of a two-step rhythm and the strength of this work lies in its rhythmic variations; augmentation; harmony; and the use of decorative tones. Indyhiang is arranged based on the pentatonic sorog scale.

Table 8. Indonesian Piano Composition Eighth Grade.

\begin{tabular}{llll}
\hline Work & Mov & Key & Composer \\
\hline Variasi Sriwijaya & 6 & $\mathrm{C}$ & Amir Pasaribu \\
Indyhiang & 1 & $\mathrm{f} \#$ & \\
Suite Villgeoise & 3 & $\mathrm{~d}, \mathrm{f}, \mathrm{Bb}$ & \\
Sonate & 2 & $\mathrm{f} \# \mathrm{~m}, \mathrm{~A}$ & \\
Tjapung Ketjimpung di Tjikapundung & 1 & $\mathrm{C}$ Dorian & \\
Kamadjaja & 1 & $\mathrm{f}$ & Moctar Embut \\
Soleram Fantasi & 1 & $\mathrm{D}$ & Trisutji Kamal \\
Variasi Gethuk & 1 & $\mathrm{C}, \mathrm{c}$ & Jaya Suprana \\
Variation on Kupu-Kupu Yang Lucu & 1 & G Lydian & Ananda Sukarlan \\
Variation on "Bintang Kecil" & 1 & Chromatic & \\
\hline
\end{tabular}

Works that are placed at an advanced grade are for concerts or recitals with technical difficulty as well as interpretation. These works are composed of different materials, scales, and tonality hybrids. Rhapsodia Lir-Ilir is arranged based on the pentatonic slendro scale with details of the 1-3, 5-7 fourth measure, and 9-11 is the 1st rotation of the pentatonic slendro from the note $C$; while bar 4-5 and 7-8 are 4 rotations of pentatonic slendro from $\mathrm{C}$ notes. The composer made changes in bar 13-26 with a hybrid method between the pentatonic scale and the $\mathrm{C}$ major scale. The use of the chord of $\mathrm{G}$ is transferred to the pentatonic scale of the tone $\mathrm{Gb}$; while the F chord is arranged in a major scale. Theoretically, combining these two scales produces a twelve-tone system as described by the author as follows: $\mathrm{Gb}-\mathrm{Ab}-\mathrm{Bb}-\mathrm{Db}-\mathrm{Eb}-$ (G) + C - D - E - F - G - A - B - (C) = C - Db - D - Eb - E - F - $\mathrm{Gb}-\mathrm{G}-\mathrm{Ab}-\mathrm{A}-\mathrm{Bb}-\mathrm{B}-(\mathrm{C})$. The addition of $\mathrm{Db}$ and $\mathrm{Ab}$ notes in the pentatonic slendro scale (bar 42-139) has made it similar or identical to one of the Arabic scales or maqam, namely Maqam Hijaz Kar.

Table 9. Indonesian Piano Composition Advance Grade.

\begin{tabular}{llll}
\hline Work & Mov & Key & Composer \\
\hline Sunda Sea Scapes & 7 & Chromatic & Trisutji Kamal \\
Interludium & 1 & Chromatic & Jaya Suprana \\
Sonata Sekar Setaman & 3 & d, a, C & \\
Rapsodia Lir-Ilir & 1 & Chromatic & \\
Uro-Uro & 1 & G & \\
Dedemit & 1 & Bi-tonality & \\
Fantasia Arum Dalu & 1 & e & Ananda Sukarlan \\
Rapsodia Nusantara No 1 & 1 & Chromatic & \\
Rapsodia Nusantara No 2 & 1 & Bb, C, B, A, D, F & \\
Rapsodia Nusantara No 3 & 1 & C, A, G, F & \\
Rapsodia Nusantara No 4 & 1 & F, A & \\
Rapsodia Nusantara No 5 & 1 & C, Eb, E & \\
Rapsodia Nusantara No 6 & 1 & E, B, A & \\
Rapsodia Nusantara No 7 & 1 & C, Ab, F\#, A & \\
Rapsodia Nusantara No 8 & 1 & C, G, Eb & \\
\hline
\end{tabular}

\section{Conclusion}

Composers Amir Pasaribu, Mochtar Embut, Trisutji Kamal, Jaya Suprana and Ananda Sukarlan have contributed greatly to the development of music in Indonesia. Their works are arranged according to various Indonesian musical idioms and folk songs 
have formed a serious musical identity in Indonesia. On the one hand, many pianists have chosen their works as a repertoire to be performed in various music concerts and recitals nationally and internationally. On the other hand, Indonesian piano work is used as learning material in formal and non-formal education in Indonesia. However, we find that using Indonesian composers' piano works as learning material has not been systematically arranged by level. Therefore, this study discusses the use of piano Indonesian compositions based on grade. The Indonesian piano curriculum can be adjusted to the current current curriculum for the preparation of this curriculum based on the scale, sight-reading, and aural considerations of each level used by ABRSM, LCM, and Trinity.

This research can be an 'entrance' to the use of piano works by Indonesian composers as a music curriculum in formal and non-formal music education institutions in Indonesia. Of course, it requires a common view and willingness of all stakeholders in discussing matters related to the preparation for the implementation of Indonesian piano works in the music curriculum.

The author realizes that the topic of this research is an initial article that discusses music education in Indonesia. Therefore, there has been wide open space for further research on various topics such as;

(1) learning strategies for Indonesian piano works in formal and non-formal education based on a cultural approach;

(2) the impact of learning Indonesian piano works in building the identity of pianists or students in performances;

(3) analysis of the implementation of the Indonesian piano education curriculum in formal or non-formal educational institutions;

(4) the style of Indonesian composers' piano works in historical trajectories.

\section{Acknowledgements}

The authors would like to thank the HKBP Nommensen University Foundation and the Ministry of Education, Culture, Research, and Technology for encouraging and supporting this research.

\section{References}

[1] Gunardi, Levi. (2015). Imaginary World: 24 Piano Pieces. Jakarta: CV. Volume Ilmu Pratama, iii-vii.

[2] Simanjuntak, H. L. (2019) "The Use of Indonesian Composers' Piano Works in Music Education". Personal Communication: December 5, 2019.

[3] Suprana, Jaya. (2019). Jaya Suprana-Vol 1 Edisi 3. Jakarta: Pustaka Sekolah Musik, Yayasan Pendidikan Musik, 1-20.

[4] Suprana, Jaya. (2009). Dedemit. Jakarta: Pustaka Sekolah Musik, Yayasan Pendidikan Musik, 1-18.
[5] Suprana, Jaya. (2009). Rapsodia Lir-Ilir. Jakarta: Pustaka Sekolah Musik, Yayasan Pendidikan Musik, 1-11.

[6] Suprana, Jaya. (2009). Untuk Ayla I-IV. Jakarta: Pustaka Sekolah Musik, Yayasan Pendidikan Musik, 1-12.

[7] Suprana, Jaya. (2009). Uro-Uro \& Uri-Uri. Jakarta: Pustaka Sekolah Musik, Yayasan Pendidikan Musik, 1-7.

[8] Suprana, Jaya. (2009). Fantasi Arum Dalu. Jakarta: Pustaka Sekolah Musik, Yayasan Pendidikan Musik, 1-14.

[9] Simanjuntak, H. L. (2020) "Mandatory Piano Curriculum". Personal Communication: 27 August 2020.

[10] Simanjuntak, H. L. (2020) "Implementation of Indonesian Piano Works in Compulsory Piano Courses". Personal Communication: 27 August 2020.

[11] Simanjuntak, H. L. (2018). "Piano Composition by Indonesian Composers". Personal Communication: 16 August 2018.

[12] Dewantara, Ki Hadjar. (1967). Karja: Bagian IIA: Kebudajaan. Jogjakarta: Percetakan Taman-Siswa, 200.

[13] Notosudirdjo, Franki S. (2001). "Music, Politics, and the Problems of National Identity in Indonesia". Disertasi untuk mendapatkan gelar Doctor of Philosophy dari University of Wisconsin-Madison, 132.

[14] Kamal, Trisutji. (2002). Sunda Seascapes Volume 1. Jakarta: PT Yulia Agung Pratama., 1-45.

[15] Burnett, Henry and Nitzberg, Roy. (2016). Composition, Chromaticism, and the Developmental Process: A New Theory of Tonality. London and New York: Routledge, 1-12.

[16] Simanjuntak, H. L. (2020). "Jaya Suprana's Piano Composition". Personal Communication: 09 September 2020.

[17] Simanjuntak, H. L, Simatupang, L. L, and Ganap, Victor. (2019) "Discourse on Indonesian Piano Composition for Music Education". Proceedings of the Social Sciences, Humanities and Education Conference, 306-309.

[18] Kamal, Trisutji. (1983). Komposisi untuk Piano Tunggal. Jakarta: PT Gramedia, 25-35.

[19] ABRSM. (2020). Piano Syllabus 2021 \& 2022. The Associated Board of the Royal Schools of Music, 11-36.

[20] LCM. (2018). Piano Grade: Syllabus 2018-2020. University of West London, 1-44.

[21] Trinity. (2017) Piano Syllabus 2018-2020. Trinity College London, 15-70.

[22] Labuta, Joseph A and Smith, Deborah A. (1997). Music Education: Historical Contexts and Perspectives. Upper Saddle River, NJ: Prentice Hall, 57.

[23] Jorgensen, E. R. (1988). Curriculum design in music. College Music Symposium 28: 94-105.

[24] Edith Widayani, "Komposisi Piano dan Identitas Pianis Indonesia" dalam Webinar Indonesian Classical Music Goes International, Saint John's Catholic School, Jakarta, 21 Agustus 2020. 